\title{
Effect of Shale Properties on Wellbore Instability during Drilling Operations: A Case Study of Selected Fields in Niger Delta-Nigeria
}

\author{
${ }^{1}$ Okafor, I.S. ${ }^{1}$ Joel, O.F., ${ }^{2}$ Iyuke, S.E., ${ }^{3}$ Ubani, C.E, ${ }^{3}$ Ndubuisi E.C. \\ ${ }^{1}$ World Bank Africa Centre of Excellence, Centre for Oilfield Chemical Research, \\ University of Port Harcourt. \\ ${ }^{2}$ University of Witwatersrand, South Africa, \\ ${ }^{3}$ Department of Petroleum Engineering, University of Port Harcourt
}

\begin{abstract}
Drilling through shale formation can be challenging and sometimes results in wellbore instability problems due to the reaction between hydrophilic shale and drilling fluids. The study of wellbore stability in shale is quite important because $75 \%$ of all formation drilled worldwide are shale formations and $90 \%$ of all wellbore instability problems occur in shale formations costing the industry more than \$1 billion USD/year. This study was carried in selected fields (FIELD A and FIELD B) in Niger Delta, Nigeria to evaluate the properties of the shales and its effects in wellbore instability during drilling operations. The properties evaluated are the shale's permeability, cation exchange capacity, and mineralogy composition. The X-Ray diffraction method was used to ascertain the mineral content and distribution of the selected shale samples across the wells in the fields $A$ and B. Results obtained showed that the shale samples had typically very low permeability between $0.1353 \mathrm{md}$ to $0.2110 \mathrm{md}$. The cation exchange capacity of the shales was observed to be low also, between (2.5-10.5)Meq/100g. The mineralogy of the shale results obtained showed that several clay minerals were identified, including palygorskite, nacrite, kaolinite, chlorites among others. Smectite group of clay minerals was observed as mixed layers in the form of sodium montmorillonite and ChloriteMontmorillonite. Also test results indicated that samples in field A contained 55\% clay minerals and 45\% nonclay minerals, while samples in field B contained 58\% clay minerals and $42 \%$ non-clay minerals. This is an indication that swelling tendencies of shale arising from drilling mud interaction with the shale even in the same well depends on the depth, shale composition mud type and composition.
\end{abstract}

\section{INTRODUCTION}

The world oil industry has been plagued by the challenges of borehole instability caused by shale during and after drilling. This challenge (shale instability) has been directly connected to several hole problems and indirectly linked to an enormous yearly expenditure for the industry. According to $\mathrm{Yu}$ et al., 2002; Zeynali, 2012, it is estimated that in terms of monetary value, the petroleum industry losses up to one billion (\$1Billion) US dollars annually due to the problem of instability of shale. Also the lost time due to this challenge accounts for over $40 \%$ of all drilling related non-productive time (Zhang et al, 2009) and these wellbore instabilities are also responsible for 10-20\% of the total drilling cost. Despite the study of shale instability for several years, it is still a critical challenge in the oil industry and even in other industries, notably the mining and construction industries. A solution to this challenge is very critical to sustaining the investment made by companies in the oil industry.

It has been noted that shale makes up to 75 percent of all drilled formations worldwide and that over $90 \%$ of the instability challenges occur in shale formations (Steiger and Leung, 1992; Dzialowski et al, 1993). It is therefore an interesting proposition to study the properties of these shale formations that make it prone to instabilities. Shales have been generally defined as sedimentary rocks with small pore radii, low permeability, medium to high clay content, and manageable porosity (Zhang, 2005). They also contain some minerals including calcite, feldspar and quartz (Osisanya, 1991). According to Manohar (1999), the distinguishing features of shale are its clays and low permeability, resulting in poor inter-connection through its characteristic narrow pore throats (pore throat diameters are within $3 \mathrm{~nm}$ to $10 \mathrm{~nm}$ ). Shales are porous and normally saturated with formation water. 


\section{Okafor, I.S et al.}

Clays are hydrous aluminium phyllosilicates sometimes with variable amounts of iron, magnesium, aluminium, alkali metals, alkali earth metals and other cations found in or near the surface of the earth. Shales comprise clay minerals and non-clay mineral fractions, the clay fraction comprises Kaolinite Group, Smectite Group, Chlorites, Illites, Mica and Palygorskite Group whereas the nonclay mineral fractions comprise silica, feldspars, Zeolites carbonates and sulphates (Moorhouse, 1958; Grim, 1968; Martin - Vivaldi and Robertson, 1971).

Its properties are usually affected by several factors including burial depth, the amount and type of pore water, water activity, the amount and type of minerals present in them (Alizadeh, 2011; Joel, et al. 2012). These special characteristics make them likely to be affected by different phenomena including swelling, shrinkage, hydration and mechanical failure.

It is believed that unfavorable interactions between shale and drilling fluids are the primary cause for wellbore instability. This interaction causes physiochemical and mechanical property alterations, making the formation wellbore to be unstable. An analysis of the intrinsic physical and chemical properties of shale will help us understand the problems and lead to better formulation of drilling fluids (Osisanya, 1991; Breeden and Shipman, 2004). In many cases, the solutions to wellbore instability problems can be developed on the basis of laboratory test results.

\section{Materials AND Method}

$\mathrm{X}$-Ray diffraction data of the shale samples from the fields were used in the semi-quantitative interpretation. The bulk composition of the shale samples was determined using the Table of Key Lines in X - Ray Powder Diffraction Patterns of Minerals in Clays and Associated Rocks (1997).

Twenty-three (23) shale samples across two (2) fields from the Niger Delta region were used for this study. Thirteen (13) samples were taken from different wells and depths across field A and ten(10) samples from field B. The shale samples were characterized using the standard test procedures as applicable.

1. Mineralogy and Clay Content Analysis - X-Ray Diffraction

2. Permeability-Permeameter

3. Cation Exchange Capacity - Methyl Blue Test

Table1. Selected Wells and their depths Field A (4750ft - 12660ft)

\begin{tabular}{|c|c|c|}
\hline S/No & Well Number & Depth (Feet) \\
\hline 1 & 2B & $4750-4780$ \\
\hline 2 & 2B & $6330-6360$ \\
\hline 3 & 2B & $7260-7290$ \\
\hline 4 & 3A & $8100-8130$ \\
\hline 5 & 3A & $8680-9110$ \\
\hline 6 & 4B & $10065-10080$ \\
\hline 7 & 4B & $10110-10125$ \\
\hline 8 & 6A & $12390-12405$ \\
\hline 9 & 6A & $12570-12584$ \\
\hline 10 & 6A & $12645-12660$ \\
\hline 11 & 6B & $12390-12405$ \\
\hline 12 & 6B & $12645-12660$ \\
\hline 13 & 6C & $12645-12660$ \\
\hline
\end{tabular}

Table2. Selected Wells and their depths in Field B (1525ft-9885ft)

\begin{tabular}{|c|c|c|}
\hline S/No & Well Number & Depth (Feet) \\
\hline 1 & 1B & $1525-1560$ \\
\hline 2 & 1B & $3540-3570$ \\
\hline 3 & 1B & $4650-4680$ \\
\hline 4 & 2B & $4915-4930$ \\
\hline 5 & 2B & $5575-5590$ \\
\hline 6 & 2B & $5635-5650$ \\
\hline 7 & 5A & $6820-6835$ \\
\hline 8 & 5A & $7375-7390$ \\
\hline 9 & 2C & $7870-7885$ \\
\hline 10 & 2C & $9130-9139$ \\
\hline
\end{tabular}


Effect of Shale Properties on Wellbore Instability during Drilling Operations: A Case Study of Selected Fields in Niger Delta-Nigeria

\section{RESUlTS AND DisCUSSIONS}

Table3. Clay and Non-Clay Mineral Composition of wells in Field A

\begin{tabular}{|c|c|c|c|c|c|c|}
\hline $\begin{array}{c}\text { WELL } \\
\#\end{array}$ & Depth (ft) & $\begin{array}{c}\text { Number of } \\
\text { minerals }\end{array}$ & $\begin{array}{c}\text { Number of } \\
\text { clay } \\
\text { minerals }\end{array}$ & $\begin{array}{c}\text { Number of non- } \\
\text { clay minerals }\end{array}$ & $\begin{array}{c}\% \text { of } \\
\text { clay } \\
\text { minerals }\end{array}$ & $\begin{array}{c}\% \text { of non- } \\
\text { clay } \\
\text { minerals }\end{array}$ \\
\hline 2B & $4750-4780$ & 9 & 3 & 6 & 61.84 & 38.16 \\
\hline 2B & $6330-6360$ & 22 & 7 & 15 & 52.79 & 47.21 \\
\hline 2B & $7260-7290$ & 11 & 3 & 8 & 65.46 & 35.54 \\
\hline 3A & $8100-8130$ & 11 & 3 & 8 & 53.83 & 46.17 \\
\hline 3A & $8680-9110$ & 10 & 3 & 7 & 63.17 & 36.83 \\
\hline 4B & $10065-10080$ & 10 & 3 & 7 & 59.05 & 40.95 \\
\hline 4B & $10110-10125$ & 17 & 5 & 12 & 44.20 & 55.80 \\
\hline 6A & $12390-12405$ & 12 & 3 & 9 & 49.55 & 50.45 \\
\hline 6A & $12570-12584$ & 10 & 3 & 7 & 62.0 & 38.0 \\
\hline 6A & $12645-12660$ & 11 & 2 & 9 & 58.40 & 41.60 \\
\hline 6B & $12390-12405$ & 10 & 3 & 7 & 56.66 & 43.34 \\
\hline 6B & $12645-12660$ & 9 & 3 & 6 & 53.87 & 36.13 \\
\hline 6C & $12645-12660$ & 30 & 3 & 27 & 38.04 & 61.96 \\
\hline
\end{tabular}

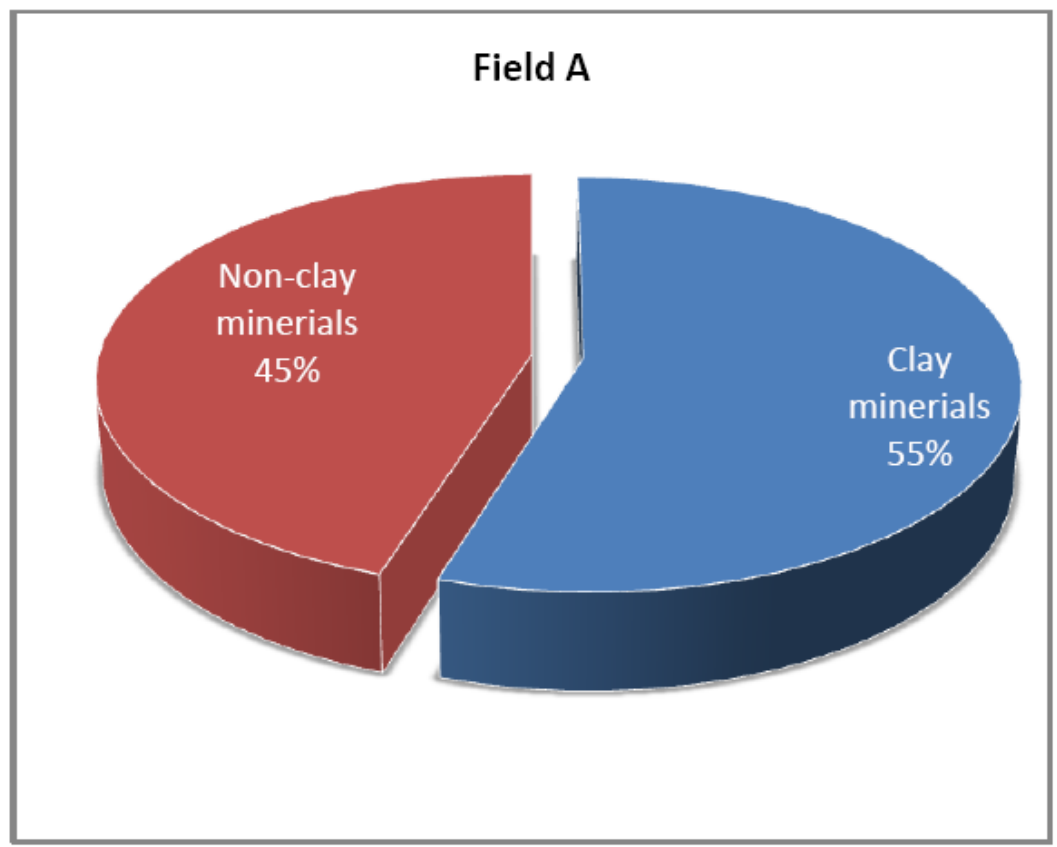

Fig1. Clay and Non Clay Mineral Distribution Field A

\section{Shale Characterisation}

The results from the XRD analysis in terms of clays and non - clays minerals and their volume by percentage in the samples from the two the fields are presented as follows.

\section{Field A: Shale Mineralogy}

Clay types identified in this field include Palygorskite, Nacrite, Kaolinite, Chlorite, Brookite, Lizardite, Sepiolite, montmorillonite, Chlorite-Montmorillonite and Mica-Montmorillonite

The major clay minerals in this field include Palygorskite, Nacrite and Kaolinite whereas the minor clay minerals are Chlorite, Brookite, Sepiolite, montmorillonite, Chlorite-Montmorillonite and MicaMontmorillonite. This indicates minimal presence of swelling clays (Smectite). Table 3 shows the percentage distribution of clay(55\%) and non-clay(45\%) minerals within the samples collected across the different depth of the selected wells in the field. 
Okafor, I.S et al.

Table 4. Clay and Non-Clay Mineral Composition of Wells in Field B

\begin{tabular}{|c|c|c|c|c|c|c|}
\hline $\begin{array}{c}\text { WELL } \\
\#\end{array}$ & Depth (ft) & $\begin{array}{c}\text { Number of } \\
\text { minerals }\end{array}$ & $\begin{array}{c}\text { Number of } \\
\text { clay } \\
\text { minerals }\end{array}$ & $\begin{array}{c}\text { Number of } \\
\text { non-clay } \\
\text { minerals }\end{array}$ & $\begin{array}{c}\text { \% of clay } \\
\text { minerals }\end{array}$ & $\begin{array}{c}\text { \% of non- } \\
\text { clay minerals }\end{array}$ \\
\hline 1B & $1525-1560$ & 10 & 3 & 7 & 61.61 & 37.39 \\
\hline 1B & $3540-3570$ & 14 & 3 & 17 & 48.98 & 51.02 \\
\hline 1B & $4650-4680$ & 11 & 4 & 7 & 50.94 & 49.06 \\
\hline 2B & $4915-4930$ & 12 & 3 & 9 & 54.49 & 45.41 \\
\hline 2B & $5575-5590$ & 8 & 2 & 6 & 65.94 & 34.06 \\
\hline 2B & $5635-5650$ & 18 & 4 & 14 & 56.34 & 43.66 \\
\hline 2C & $7870-7885$ & 11 & 4 & 7 & 59.01 & 40.99 \\
\hline 2C & $9130-9139$ & 10 & 3 & 7 & 62.05 & 37.95 \\
\hline 5A & $6820-6835$ & 11 & 3 & 8 & 54.34 & 45.66 \\
\hline 5A & $7375-7390$ & 13 & 3 & 10 & 54.34 & 45.66 \\
\hline
\end{tabular}

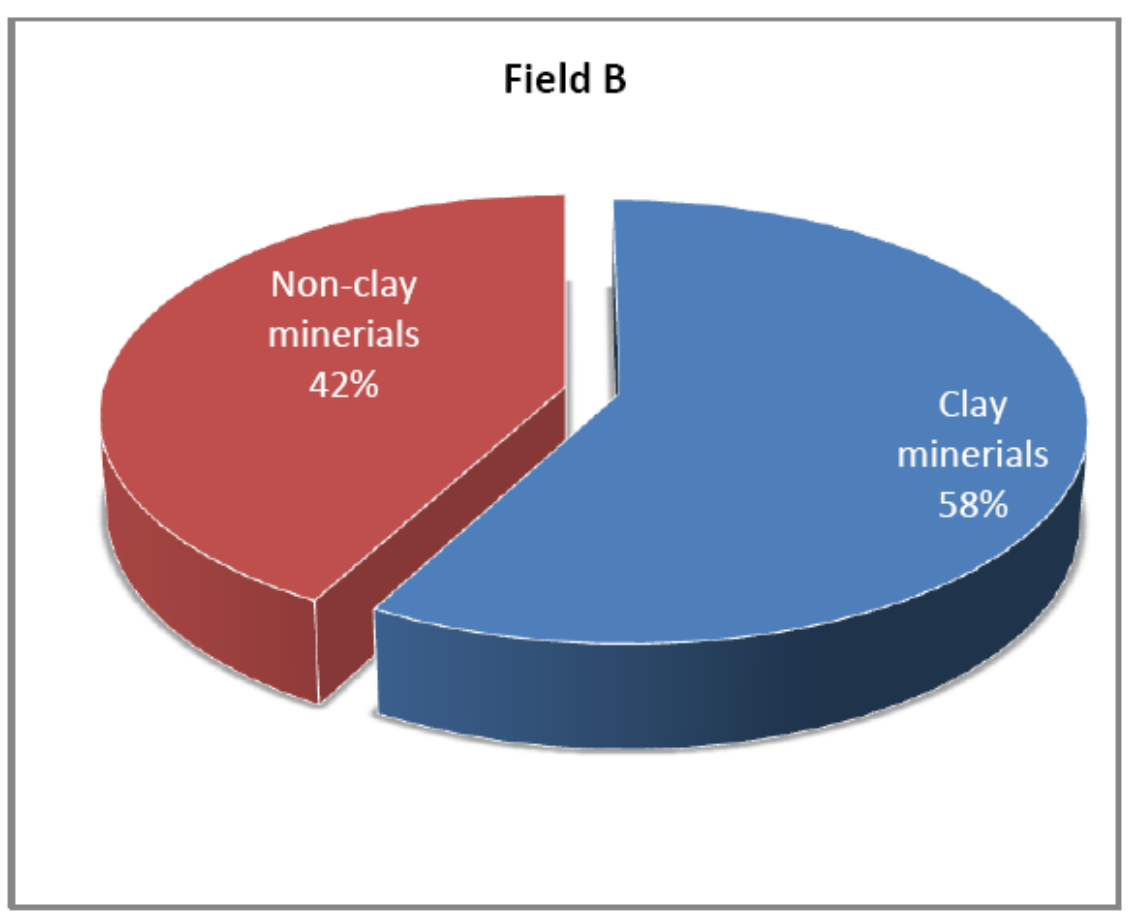

Fig2. Clay and Non Clay Mineral Distribution Field B

Table5. Clay Mineral Distribution of tested Samples (Field A and B)

\begin{tabular}{|c|c|c|c|c|}
\hline Clay Minerals & \multicolumn{4}{|c|}{ Proportion (\%) } \\
\hline & \multicolumn{2}{|c|}{ Field A } & \multicolumn{2}{c|}{ Field B } \\
\hline & Min & Max & Min & Max \\
\hline Palygorskite & 33.14 & 56.52 & 39 & 56 \\
\hline Nacrite & 3.32 & 5.5 & 2.5 & 6.6 \\
\hline Kaolinite & 1.5 & 6 & 1.25 & 5.16 \\
\hline Sepeolite & 1.63 & 3.12 & 2.18 & 3.4 \\
\hline Na-montmorillonite & 1.51 & 1.63 & 0 & 0 \\
\hline Montmorillonite & 1.12 & 1.32 & 0 & 1.31 \\
\hline Chlorite & 1.69 & 3.25 & 8.31 & 26.22 \\
\hline Chlorite-montmorillonite & 0 & 1.12 & 0 & 0 \\
\hline Pyrophyllite-montmorillonite & 0 & 0 & 0 & 2.2 \\
\hline Mica-montmorillonite & 0 & 1.12 & 0 & 0 \\
\hline Brookite & 0 & 1.12 & 0 & 0 \\
\hline
\end{tabular}




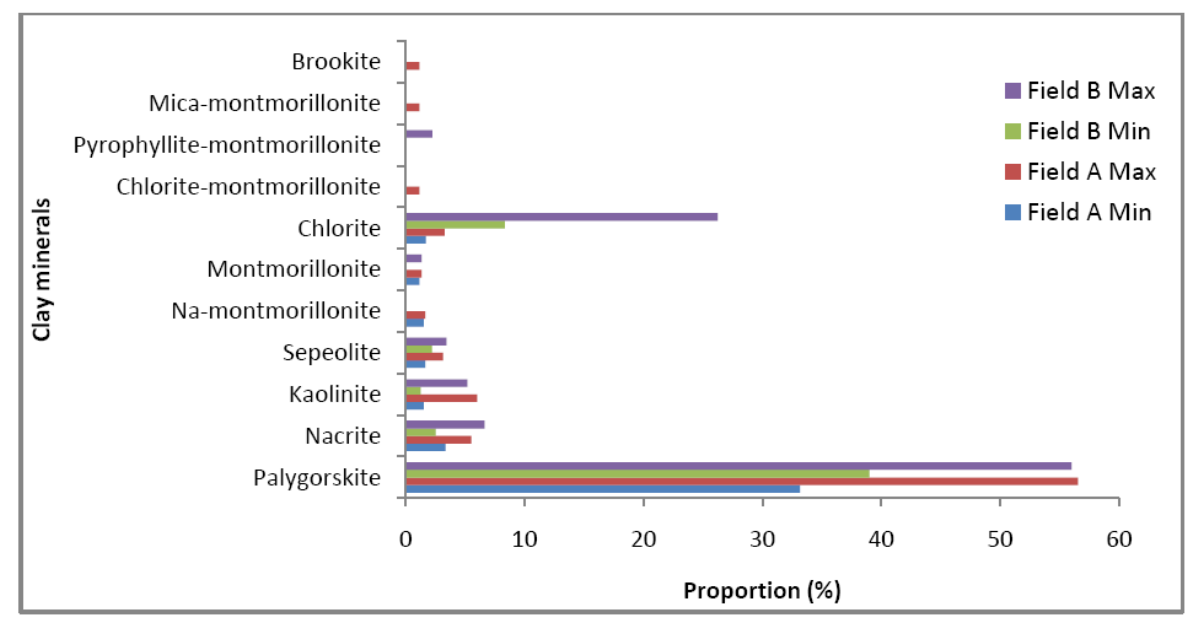

Fig3. Minimum and maximum clay mineral proportion in shales (Field $A$ and $B$ )

\section{Field B: Shale Mineralogy}

The type of clays identified in the formations (wells) of this field include palygorskite, Nacrite, Kaolinite, Chlorite, Lizardite, Sepiolite, montmorillonite, Vermiculite and PyrophylliteMontmorillonite. The clays fall into the following groups:

The major clay minerals in this well include Palygorskite, Nacrite and Kaolinite whereas the minor clay minerals are Chlorite, Sepiolite, montmorillonite, Vermiculite and Pyrophyllite-Montmorillonite. Table 4 shows the percentage distribution of clay and non- clay minerals within the samples collected across the different depth of the selected wells in the field.

In both fields, clays with potentials to swell and known as swelling clays comprise the following

1. Smectites: Montmorillonite, Brookite and Vermiculite.

2. Palygorskite Group: Palygorskite and Sepiolite

3. Mixed Layer Clays: Pyrophyllite-Montmorillonite, Chlorite-Montmorillonite, SodiumMontmorillonite and Mica-Montmorillonite.

The presence of Feldspars such as K-feldspar, Plagioclase feldspar, Albite, Anatase and Fayalite indicates that the phenomenon of shale swelling (hydration) when in contact with drilling mud may accelerate the swelling tendencies of clays in both fields. Test results indicated that samples in field A contained 55\% clay minerals and $45 \%$ non-clay minerals, while in field B contained 58\% clay minerals and $42 \%$ non- clay minerals(Figures $1 \& 2$ ). Also, the clay mineral Palygorskite, a relatively less reactive shale was the most abundant across the selected wells of the two fields, followed by Nacrite and Kaolinite. The smectite group of clay minerals (montmorillonite, brookite, vermiculite) were minimal in both fields. The distributions of clay minerals across both fields are shown in (Table 5 and Fig-3)

\section{- Shale Permeability}

The results obtained from the permeability experiment carried on the shale is presented in table- 6 . It was observed that the permeability values of the different shale samples tested were low. This is typical of shale because of its poor connectivity through narrow pore throat and agrees with other studies carried out to determine permeability of shale samples (Al Bazali, 2005; Zhang, 2005).

The permeability result was evaluated using the following equation (Darcy's law)

$q=\frac{k A \Delta P}{\mu L}$

Where

$\mathrm{q}=$ Volumetric flow rate $(\mathrm{cc} / \mathrm{sec})$

$\mathrm{k}=$ Permeability (Darcy)

$\mathrm{A}=$ Cross sectional area of core $\left(\mathrm{cm}^{2}\right)$ 
Okafor, I.S et al.

$\Delta \mathrm{P}=$ Pressure difference across core (psi)

$\mu=$ Viscosity of brine $(\mathrm{cP})$

$\mathrm{L}=$ Length of core $(\mathrm{cm})$

Table6. Permeability of Selected Shale Samples

\begin{tabular}{|c|c|c|c|c|c|c|}
\hline Core ID & $\begin{array}{c}\text { Viscosity of } \\
\text { brine (cP) } \\
@ \mathbf{2} \mathbf{2 8} \mathbf{c}\end{array}$ & $\begin{array}{c}\text { Brine } \\
\text { concentration } \\
(\mathbf{p p m})\end{array}$ & $\begin{array}{c}\text { Length of } \\
\text { Core }(\mathbf{c m})\end{array}$ & $\begin{array}{c}\text { Area of } \\
\text { core } \mathbf{( \mathbf { c m } ^ { \mathbf { 2 } } )}\end{array}$ & $\begin{array}{c}\text { Pressure } \\
\text { differential } \\
(\mathbf{p s i})\end{array}$ & $\begin{array}{c}\text { Permeability } \\
(\mathbf{m D})\end{array}$ \\
\hline A1 & 4 & 5000 & 1.94 & 28.49 & 2.238 & 0.1536 \\
\hline B3 & 4 & 5000 & 3.8 & 63.36 & 2.238 & 0.1353 \\
\hline C5 & 4 & 5000 & 2.27 & 28.59 & 0.866 & 0.2110 \\
\hline A5 & 4 & 15000 & 2.30 & 31.60 & 2.888 & 0.1590 \\
\hline B1 & 4 & 15000 & 2.04 & 29.36 & 1.5 & 0.1752 \\
\hline C3 & 4 & 15000 & 1.95 & 28.59 & 1.625 & 0.1469 \\
\hline A3 & 4 & 25000 & 2.10 & 29.88 & 1.3 & 0.2046 \\
\hline B5 & 4 & 25000 & 2.10 & 29.88 & 1.8 & 0.1971 \\
\hline C1 & 4 & 25000 & 1.78 & 27.13 & 1.6 & 0.1552 \\
\hline
\end{tabular}

Table7. CEC values for sampled shales

\begin{tabular}{|c|c|}
\hline CORE SAMPLE ID & CEC (Meq/100g) \\
\hline $2 \mathrm{~A}$ & 3.0 \\
\hline $2 \mathrm{~B}$ & 3.5 \\
\hline 4B & 6.5 \\
\hline $13 \mathrm{~A}$ & 2.5 \\
\hline $13 \mathrm{~B}$ & 3 \\
\hline $13 \mathrm{C}$ & 2.5 \\
\hline $13 \mathrm{D}$ & 2.5 \\
\hline $16 \mathrm{~A}$ & 2.5 \\
\hline $19 \mathrm{~A}$ & 6.0 \\
\hline $19 \mathrm{C}$ & 9.0 \\
\hline $22 \mathrm{~A}$ & 6.0 \\
\hline $22 \mathrm{~B}$ & 9.5 \\
\hline $22 \mathrm{C}$ & 4.5 \\
\hline $22 \mathrm{D}$ & 10.5 \\
\hline $23 \mathrm{~A}$ & 7.0 \\
\hline $23 \mathrm{~B}$ & 7.5 \\
\hline
\end{tabular}

\section{- Cation Exchange Capacity of Shale}

Results obtained for the cation exchange capacity of the tested shale samples are as presented in Table 7. The results for the cation exchange capacity can be correlated with the shale mineralogy and brine concentration for an understanding of the principle of shale swelling when exposed to brine and water based drilling mud. Shale samples are classified into low $(\mathrm{CEC}<12)$ and moderate $(\mathrm{CEC}>12)$ reactivity shale types with the low reactivity shale exhibiting low swelling and the high reactivity shale exhibiting medium swelling and high cutting disintegration (Akpokodje, 1994). The results obtained from the tested shale samples shows that they fall into the low reactivity shale samples with regards to their cation exchange capacity values ranging from $2.5 \mathrm{Meq} / 100 \mathrm{~g}$ to $10.5 \mathrm{Meq} / 100 \mathrm{~g}$ and agrees with the previous studies(Akpokodje,1994), This is also in agreement with the mineralogy and clay mineral results that is dominated by the less reactive and low swelling palygorskite, nacrite and kaolinite. Kaolinite group of minerals. They are known to have low CEC partly due to the presence of impurities and broken bonds at the edges of the mineral flakes (Ekeocha, 2015).

The results also indicated that CEC has major significance in determining clay mineral properties and as such critical in shales ability and propensity to absorb water. This is because the movement of water and even ions to and from the shale/mud during the shale/mud interaction is usually controlled and influenced by the cation exchange capacity. This implies that the shale CEC, its water holding capacity and its mineral composition plays a major role in its swelling tendencies. The higher the reactive clays (Smectite) in a shale, the higher the CEC, thus the higher the swelling capacity of the shale, this agrees with the result published by Bell, (2007). 


\section{Conclusion}

- The importance of shale properties evaluation in the study of wellbore instability caused by the interaction between shale formation and drilling fluid cannot be overemphasized in the light of the fact that most instability issues occur in shale formations.

- The shale mineralogy analysis carried out showed the dominance of clay minerals (55\%) over non clay minerals $(45 \%)$.

- The samples contained Palygorskite, Nacrite and Kaolinite as the dorminant minerals with little amount of montmorillonite and mixed clays. This was observed across the selected wells in the fields.

- Low Shale permeability was observed for the selected shale samples indicative of the samples poor pore connectivity.

- The shales were of low reactivity and swelling as indicated by its low cation exchange capacity values.

- The higher the clay content, the more likely the shale will be reactive to swelling.

- Therefore, the X-ray diffraction data can be used in conjunction with other considerations like cation exchange capacity, water activity and composition when formulating a drilling fluid for specific sections of the well.

- Test results has indicated that even in the same well, the mineralogy composition of the shale sample vary depending on the dept, therefore it is imperative to design fit for purpose and compatible drilling mud for different depths.

\section{ACKNOWLEDGEMENT}

The authors wish to acknowledge the Petroleum Technology Development Fund (PTDF) for providing funds for this research. Also we thank the World Bank Africa Centre of Excellence, Centre for Oilfield Chemical Research, University of Port Harcourt for their commitment and support.

\section{REFERENCES}

[1] Akpokodje E.G.: (1994) "Drilling Performance and Shale Problems" SPDC Technology Improvement Project Exploration Report.

[2] AL-Bazali T.M.: (2005) "Experimental Study of the Membrane Behavior of Shale during Interaction with Water-Based and Oil-Based Muds" PhD Dissertation, the University of Texas at Austin.

[3] Alizadeh, S.: (2011) "Physio-Chemical Analysis of Shale-Drilling Fluid Interaction and its Application in Borehole Stability Studies, B.Sc Project Work, Petroleum University of Technology, Iran.

[4] Bell, F.G.: (2007) "Engineering Geology" $2^{\text {nd }}$ Edition, London Elsevier, 207-248.

[5] Breeden, D. and Shipman, J.: (2004) "Shale Analysis for Mud Engineers", AADE-04-DF-HO-30 presented at the AADE 2004 Drilling Fluids Conference, at the Radisson Astrodome in Houston, Texas.

[6] Dzialowski, A., Hale, A., and Mahajan, S.: (1993) Lubricity and Wear of Shale: Effects of Drilling Fluids and Mechanical Parameters" SPE/IADC 25730.

[7] Ekeocha, N.E.: (2015) "The Mineralogical and Engineering Characteristics of Cretaceous and Tertiary Shales in Lower Benue Trough, Nigeria". Journal of Earth Science and Engineering, Pp. 487-498.

[8] Grim, R. E. (1968). Clay Mineralogy, $2^{\text {nd }}$ Edition. McGraw-Hill, New York, P 596.

[9] Joel O.F., Durueke U.J., Kinigoma B.S. and Nwokoye C.U. (2012): "Evaluation of Effect of Different Concentrations of Shale on Rheological Properties of Water-Based Mud" Research Journal of Chemical Sciences Vol. 2(10), 13-19, October.

[10] Keijzer, J.S., Kleingeld, P.J.,and Loch, J.P.G.: (1999) "Chemical Osmosis in Compacted Clayey Materials and the Prediction of Water Transport” Engineering Geology 53, Pp 151-159. 
[11] Manohar Lal, (1993): "Shale Stability: Drilling Fluid Interaction and Shale Strength" SPE 54356, BP Amoco.

[12] Martin - Vivaldi, J. I. and Robertson, R. H. S.: (1971) "Palygorskite and Sepiolite (the hormites)”. Mineralogical Society Monograph, No 31, London Pp. 255 - 275.

[13] Moorhouse, W. W. (1958). "The Study of Rocks in Thin Section" Harper and Row Publication. New York. Pp. $92-93$.

[14] Osisanya, S.O. (1991) "Experimental Studies of Wellbore Stability in Shale Formations", Ph.D Dissertation, the University of Texas at Austin.

[15] State of Indiana Geological Survey (1977). "Table of Key Lines in X - Ray Powder Diffraction" Patterns of Minerals in Clays and Associated Rocks.

[16] Steinger, R. and Leung, P.K.: (1992) "Quantitative Determination of the Mechanical Properties of Shales" SPE Drilling Engineering.

[17] Yu, M., Sharma, M. M., and Chenevert, M.E., (2003). "Chemical-Mechanical Wellbore Instability Model in Shales Accounting for Solute Diffusion" Journal of Petroleum Science and Engineering, v. 38, p. 131-143.

[18] Zeynali, M.E. (2012) "Mechanical and Physio-Chemical Aspects of Wellbore Stability during Drilling Operations" Journal of Petroleum and Engineering.

[19] Zhang J., Yu, M., Al-Bazali, T.M., Ong, S., Chenevert, M.E., Sharma, M.M., Clarc, D.E. (2006): "Maintaining the Stability of Deviated and Horizontal Wells: Effects of Mechanical, Chemical, and Thermal Phenomena on Well Designs". Paper SPE 100202, presented at the SPE International Oil \& Gas Conference and Exhibition in China.

[20] Zhang, L.W., Qiu, D.H., and Chong, Y.F. (2009) "Research on Wellbore Stability Model Coupled Mechanics and Chemistry" Journal of Shandong University, Engineering Science, Vol. 39, no. 3, Pp. 111-114 


\section{AUTHORS' BIOGRAPHY}
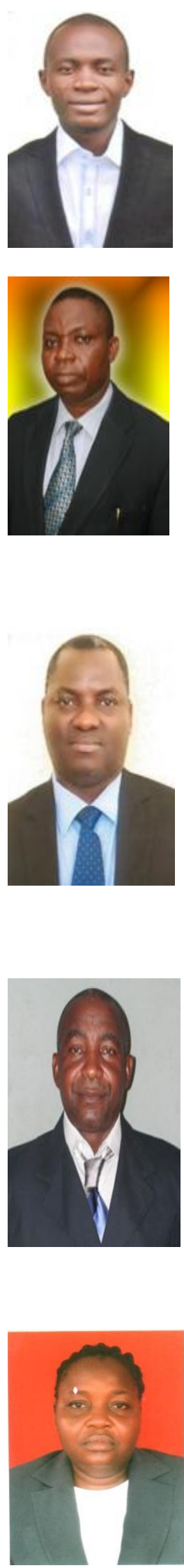

Okafor, Ikechukwu Stanley, is a young Reservoir Engineer, Research Fellow and Doctoral Candidate at the World Bank Africa Centre of Excellence, Centre for Oilfield Chemicals Research, University of Port Harcourt. He is also a member of the Nigeria Society of Engineers and an Associate Environmental Specialist with the National Registry of Environmental Professional (NREP). His research interests include enhanced oil recovery, formation evaluation, drilling fluid design and chemical wellbore instability.

Professor Ogbonna F. Joel, is a Professor of Petroleum Engineering with the University of Port Harcourt. He is the African Regional Representative of National Registry of Environmental Professionals (NREP, USA). He is presently the Head of Department, Gas Engineering,Director, Centre for Petroleum Research and Training, Institute of Petroleum Studies, as well as Centre Leader for the World Bank Africa Centre of Excellence for Oil field Chemical Research, University of Port Harcourt. He is a Subject expert in Oilfield Chemicals Research and applications. He specializes also in the management of environmental and pollution control issues in the Oil and gas Industry . He is a member of various Professional bodiies and has published widely and given numerous presentations both local and International in the area of his expertise.

Sunny Iyuke, is a Professor of Chemical and Process Engineering who was the Head of School of Chemical and Metallurgical Engineering at the University of the Witwatersrand (Wits), Johannesburg, South Africa from 2009 - 2014. Sunny has published more than 226 articles in journals and conferences worldwide. He has produced numerous patents in nanotechnology locally and internationally including World Intellectual Property Organization of International Bureau. He is a chartered Engineer with the Engineering Council, UK, Professional Engineer with the Engineering Council of South Africa and a Fellow of South African Academy of Engineering. He is one of the top nanotechnologist in South Africa. $\mathrm{He}$ is presently the CEO of Petroleum Training Institute (PTI), Efurun in Delta State, Nigeria.

ENGR. Dr. Ubani Chikwendu E., is a Senior Lecturer of Petroleum Engineering at the University of Port Harcourt, He holds a B.Tech in Petrochemical Engineering from the University of Science and Technology Port Harcourt. M. Eng and Ph.D in Petroleum \& Gas Engineering from the University of Port Harcourt. His research interests are in Fluid Flow in porous media, integrated field Studies, Petrophysics, Reservoir Engineering, PVT modeling, Log Evaluation, Coring and Core Analysis. He has co-authored over thirty (30) technical papers. $\mathrm{He}$ has over 20 years of oil field experience covering the areas of Onshore/Offshore Drilling Practices, Reservoir Engineering, Formation Evaluation, Petrophysical Analysis, Production Engineering and Petroleum Project Evaluation.

Mrs. Ndubuisi, is a Petroleum Engineer with the Department of Petroleum and Gas Engineering, University of Port Harcourt, with over 10 years industry, teaching and research experience in drilling operations, specializing in oilfield chemicals design and application for drilling and completion/workover fluids. She possesses a strong research and laboratory capability and is a subject expert in quality assurance/quality control of drilling additives and hydrocarbon products. 